\title{
THE STRATEGY OF THAI MEDICAL SERVICES PROMOTION AT FOREIGN MARKETS AND DEVELOPMENT OF MEDICAL TOURISM
}

\author{
Denis S. USHAKOV* \\ International college, Suan Sunandha Rajabhat University, \\ Bangkok, Thailand, e-mail: denis.us@ssru.ac.th
}

\section{Olena O. YUSHKEVYCH}

Department of Management and Entrepreneurship, Zhytomyr Polytechnic State University, Zhytomyr, Ukraine, e-mail: elenastrateg@ukr.net

\section{Nataliia L. OVANDER}

Department of Digital Economics and International Economic Relations, Zhytomyr Polytechnic State University, Zhytomyr, Ukraine, e-mail: natovan@ukr.net

\section{Hanna Yu. TKACHUK}

Department of Management and Entrepreneurship, Zhytomyr Polytechnic State University, Zhytomyr, Ukraine, e-mail: tkachuk.anyuta@gmail.com

\section{Volodymyr H. VYHOVSKYI}

Department of Management and Entrepreneurship, Zhytomyr Polytechnic State University, Zhytomyr, Ukraine, e-mail: vygovskyy2008@ukr.net

\begin{abstract}
Citation: Ushakov, D.S., Yushkevych, O.O., Ovander, N.L., Tkachuk, H.Yu., Vyhovskyi, V.H. (2019). THE STRATEGY OF THAI MEDICAL SERVICES PROMOTION AT FOREIGN MARKETS AND DEVELOPMENT OF MEDICAL TOURISM. GeoJournal of Tourism and Geosites, 27(4), 1429-1438. https://doi.org/10.30892/gtg.27426-445
\end{abstract}

\begin{abstract}
Aims. The main aim of the research is to develop a preliminary offer of special medical tours to Thailand for the citizens of Russian Federation; to evaluate the limits of demand for Thai national medical tour-product in Russia, the potential key features of promotion and sales of Thai medical tours in Russia under the current economic conditions. Introduction. The relevance of the study is due to the fact that more than 50 countries of the world see the provision of medical services to international patients as the top-priority area of their national development. Leading approach to the study of this problem is the comparative method that has afforded revealing peculiarities of promoting Thai medical tours and potential sales to foreign patients. Results. The paper identifies the role of medical services in the process of Thai national tourist product differentiation and describes some of the special medical tours in Thailand specifically designed for overseas markets. The authors also evaluate the limit of demand for the national medical tour product of Thailand. Inerpretation. The authors emphasized the importance of promoting an excellent and high-tech service in promoting the Thai wellness product. The article
\end{abstract}

\footnotetext{
* Corresponding author
} 
also suggests checking the economic and marketing effectiveness of the business model of a sanatorium in Thailand. This model will be somewhat more expensive than a traditional hotel, but, unlike a hotel, it will have a number of strong competitive advantages in terms of Russian sales and will be able to actively earn additional services. The materials of the paper imply the practical significance for the university teachers of the economic specializations.

Key words: medical tourism, healthcare, medical services, insurance, overseas markets

\section{INTRODUCTION}

Under conditions of globalization, the level and the quality of medical services have become rather levelled in many countries, thus, only the price factor becomes a determinating factor of country's competitiveness when it comes to medical services' provision at the world markets. In this regard, gradually forming is the flow of patients from the countries with well-developed healthcare systems to the emerging markets with the opportunity to obtain good quality medical services at more competitive prices (Table 1). Population of Russia has a big potential for health and medicine services consumption from abroad (Chistobaev \& Semenova, 2018). A very important feature of these markets is wider perspectives for foreign (first of all, Western, then Asian) medical services' supply (Sukhova et al., 2018; Zhuravleva et al., 2018).

Under such conditions and preferences Thailand (while its healthcare industry is obtaining several global advantages) gets enough chances to participate in sharing these markets. This would provide more stabile income for domestic population from the inflow of more medical tourists, and at the same time this will also differentiate Thai national tourism products' range (Grasso, 2014; Chkalova et al., 2019).

Table 1. Comparasion of Price Rates for Medical Services in the Selected Countries of the World (\%, 2016) (Keckley, 2017)

\begin{tabular}{|l|l|c|l|l|l|}
\hline 1 & USA & $100 \%$ & 5 & Mexico & $40-60 \%$ \\
\hline 2 & Costa Rica & $45-65 \%$ & 6 & Singapore & $25-40 \%$ \\
\hline 3 & India & $65-90 \%$ & 7 & South Korea & $40-45 \%$ \\
\hline 4 & Malaysia & $60-80 \%$ & 8 & Thailand & $50-75 \%$ \\
\hline
\end{tabular}

The main purpose of this research has helped us identify the complex of the related research objectives:

- To identify the role of medical services (plastic surgery, cosmetology and beauty industry) in differentiating of Thai national tourist product;

- To develop a preliminary offer of special medical tours to Thailand for the citizens of Russian Federation. To evaluate the limits of demand for Thai national medical tourproduct in Russia, the potential key features of promotion and sales of Thai medical tours in Russia under the current economic conditions;

- To develop a strategy for international marketing of Thai clinics, to determine the most salable features of Thai medical services at international markets;

- To present authors' own project on Russian customers' attraction to Thai clinic (including: the pricing strategy, promotion, extra services, international distribution, sales and services' modification etc.). 


\section{METHODOLOGY}

The data collection has been made by means of survey of two large groups of people: the first were foreigners currently living in Thailand (in Bangkok and in Pattaya), and the second were foreigners, permanently living in Russia (Verdugo-Perona et al., 2016). The overall number of the respondents was 120 from 6 countries of the world. All travellers were chosen to be older than 18 years old. All surveyed travellers had made the decisions concerning medical treatments by themselves. All travellers needed some medical treatment, however, were able to travel by themselves and/or bought the tour packages independently (Aimagambetov et al., 2017).

Research Instruments (Including the statement of validity and reliability):

The questionnaire contained 29 questions overall, including only 2 open questions. The questions covered the respondents' personal data, trip details and also future plans information (Buathong \& Lai, 2019; Font \& Lynes, 2018).

Data Collection Procedures:

Places chosen for this survey were the following:

- hotels of different categories, located in various parts of both cities. To meet the objectives of this study we will focus only on the hotels of high category (the distribution of hotels of different categories in the total number of the hotels was as follows: 5 -star hotels - 30\%, 4-star - 35\%, 3-star - 25\%);

- tourist information centers (King \& Lertnapakun, 2019);

- medical tourism exhibition (in Moscow, Russia);

- healthcare and medical tourism international congress (Moscow, Russia).

The questionnaires had been made in three languages (Thai, Russian, English).

\section{THEORETICAL CONTEXT}

\section{Thailand Within the Global Medical Tourism Context Today}

In recent years' medical tourism in Thailand has shown quite impressive growth rates. According to the official data, $20 \%$ of all foreign tourists are also the participants of medical tourism. In 2016, 1.85 million tourists visited Thailand for medical purposes, $33 \%$ of them were US citizens, $29 \%$ were coming from China and $18 \%$ - from Japan. In 2016 , the total income of Thai clinics was over $\$ 2$ billion. It is important to mention in this regard that the price for medical services for foreigners and Thai residents is the same (Aizura, 2017), unlike in many other sectors, especially in tourism-related (De Arellano, 2007). In Thailand overall there are more than 1000 hospitals, 470 of them are private. The largest private hospital in Asia, and the first Asian hospital, certified according to the ISO 9001 and accredited by the JCI are also located in Thailand. Today 37 hospitals in Thailand have the JCI accreditation, and all of them are privately owned. The medical tourism industry in Thailand is promoted, firstly, by private hospitals. Thai doctors are happy to work in international clinics, where they earn at least $70 \%$ more than in public hospitals. Medical tourists come to Thailand from almost all countries of the world (Aizura, 2017). The most active countries and regions in this regard are: Japan, the Middle East, USA, China, Great Britain, Western Europe, Australia (Smith \& Puczko, 2013; Momeni et al., 2018). Among the factors determining the inbound medical tourism development in Thailand we can identified the following:

- competitive costs of medical treatment overall. The cost of treatment in Thailand is only a small fraction of the cost of appropriate procedures in most Western countries. Prices for treatment are usually 20-50\% lower than in most of the Western countries. Such low costs allow patients not only pay in full for all the related services, but also take some rest at Thai famous resorts after complicated medical procedures; 
Denis S. USHAKOV, Olena O. YUSHKEVYCH,

- high quality of medical services in the country;

- well-developed tourist infrastructure.

Thailand is one of the leading tourist destinations in the world - a paradise with unique beaches and delightful views (Lerdsuchatavanich et al., 2016; Nonthapot \& Srichaiyo, 2017; Saraithong \& Chancharoenchai, 2017; Khan, 2017; Nonthapot et al., 2018). The country has a rich culture and an amazing cuisine, people are friendly and always nice to foreigners. Due to the tourism factor, the level of services overall is very high, this indirectly contributing to the success of medical tourism as well. Thais make every effort to provide the highest level of satisfaction with servies for all visitors. Accordingly, foreigners are happy to receive such a high level of service, whether in a hotel or in a hospital (Connell, 2006).

\section{Russia as a Market for Thai Health Services}

Interest in medical tourism in Russian Federation is quite high. About 6.2 million Russian-speaking users of Yandex.ru (the most popular Russian search engine) are monthly monitoring the offers of medical care abroad. For example, only the request "treatment in Germany", according to the search engine Yandex data, is searched for by about 10 thousand unique users (Vetitnev \& Dzubina, 2013). This high interest is explained by the unsatisfactory state of medical care in Russia.

The Russians are extremely unhappy with the level of services provided by the national healthcare. According to the research carried out by Russian sociologists, 53\% of the citizens surveyed in Russia assess the general healthcare status in Russia as "bad," "satisfactory" was chosen by only $40 \%$, and "good" was the reply of only $5 \%$ of Russian respondents (Vetitnev \& Dzubina, 2013). About 34\% of Russian doctors consider the current state of the healthcare sector in Russia as unsatisfactory.

Wealthy citizens of Russia now choose other countries that are providing higher level of medical services. The leading positions in the list of countries popular among this category of Russian tourists take Israel (45\%) and Germany (20\%). Interest and trust for these countries when it comes to medical services' provision can be explained by several, rather external factors, inter alia: absence of language barrier (due to large numbers of emigrants in both Germany and Israel from Russian), relatively close geographical location (at least for those who reside in the European part of Russia), and by the overall popular image of medical successes affiliated to these countries. Further in the ranking of popularity go Turkey, Singapore, and Switzerland, France and then such countries of Eastern Europe such as Poland, Hungary, Czech Republic and Lithuania (Burkett, 2007).

The most popular medical services among the Russians (for many years by now) are such areas as cardiology and cardiosurgery, transplantology, eye surgery, oncology, orthopedics, plastic surgery, neurosurgery. All those areas require the availability of sophisticated and thus quite expensive equipment as well as highly qualified personnel with both skills and experience so that to carry out the needed diagnostics and then treatment. Other directions in medical services which are gaining popularity today are all services related to pregnancy and delivary and also all sorts of medical rehabilitation, including those for professional sportsmen. Among the foreign health resorts, Central and Eastern European countries are preferable for the Russians, including primarily the Balkans and the Baltics (66\%), Western and Northern Europe, including Iceland (44\%), and also the selected countries of North-East and South-East Asia (40\%).

As a market for Thai tourist product sale, Russia is also interesting because of Thailand's tourism potential popularity at this market, the presence of Russian-speaking diaspora in many cities of Thailand. This, on the one hand, provides the demand for services among Russian-speaking consumers during the low tourist season, and on the 
other, this also creates more opportunities to find Russian-speaking staff for Thai clinics (for example, to provide translation of medical documents or for the interpretation of medical consultations). Equally important is the availability of regular transport connections of Thailand cities with some of the Russian regions (primarily via charter flights, which is very important since those are relatively cheap), as well as minimum visa formalities while entering the country (Abaydeldinov \& Kala, 2016; Veretekhina et al., 2017). Meanwhile, there are also problems that limit the opportunities for further Thai health tourism promotion, for example, reduction of Russian tourism market capacity (including the medical tourism market) as a result of the economic crisis and devaluation of the ruble exchange rate in 2014, sharp increase in differentiation of Russia tourist demand structure (wealthier clients prefer to be treated in Europe, the United States, Israel etc., while middle-income consumers, for whom Thailand could be potentially attractive, as of today have reduced their family expenses on tourist trips. Additionally, we should mention weak popularity of Thai health tourism, especially in the regions of Russian Federation. For many Russians, Thailand as a destination in medical tourism, is limited only to massages and sex-swap surgeries (Balaban \& Marano, 2010).

\section{RESULTS AND DISCUSSION}

After analyzing in details all the answers obtained from this questionnaire we have come up with the following conclusions:

1. Most Russian tourists (56\%) are aware of the health tourism potential of Thailand. $42 \%$ of the surveyed tourists noted the positive attitude towards the treatment in the Kingdom of Thailand. However, it should be also noted that only $15 \%$ of the surveyed had any personal experience (or that of close friends, relatives etc.) with geting medical help (or undergoing medical examination) in Thailand. This shows that Thailand has a positive reputation as a place of treatment for the Russians, and Thai medicine initially (even before the direct, actual purchase of a service) has a positive image among the Russians (Ehrbeck et al., 2008).

2. The sources of information about the state of Thai medicine, mentioned by the interviewed, vary. As quastionnarie showed, scientific sources and articles, including those posted on the Internet, are the most popular sources of information about the state of Thailand medicine and treatment for Russian tourists in particular. More than $22 \%$ of the respondents stated they received information about the state of medical tourism in Thailand from television and expert interviews. Performance of national tourist offices in this regard is rather poor, their activities had virtually no influence on the choice of our respondents. This allows us conclude that tours to Thailand, sold in Russia, are concentrated in the hands of tourism operators of mass demand. And this does not contribute to forming the necessary information support for Thailand as a popular medical tourism destination. A Russian tourist who is accustomed to trusting his/her health to professionals, and in the understanding of most Russians, a professional must be necessarily affiliated to an official organization which has all necessary documentation, licenses, qualified personnel etc. This means that such a tourist will never consider the option of buying a treatment tour at the office of a standard mass tourism operator. This, in turn, determines the need to modernize the sales system for Thailand's national medical product on the territory of Russian Federation (Department of Health Annual Report 2016-17, 2017).

3. As the main advantages of health tourism in Thailand, Russian tourists identified, first of all, quality of the care provided (42\%) and availability of necessary infrastructure (for example, when everything is nearby, there are no queues, patients 
are able to plan all procedures in advance, ease of diagnostics etc) (18\%), as well as the possibility of combining treatment with recreation, or treatment with follow-up rehabilitation (12\%). The price advantage factor proved to be much less important for the Russians than, for example, for German or Australian tourists (8\% against 37\% and $34 \%$ respectively), which in general is easy to explain by the the exchange rate of Russia's currency falling in 2014 and rise in price of any imported services for the Russians by almost twice. And also because medical treatment in Thailand is mostly chosen by the Russians with medium incomes (wealthy Russians prefer treatment in European countries, Israel and the USA), for which the price factor remains of vital importance and the cost of treatment in Thailand remains to be perceived at high level (as compared with Russian prices for medical services).

4. Only $21 \%$ of the polled Russians believe that Thai medicine is more technologically advanced and overall better developed than Russian medicine. This low percentage can be explained, rather, not by the real state of affairs, but by the fact that the Russians prefer to do serious operations not in Thailand, but at home (which is cheaper or may be free for some categories of patients or in some cases of the quota of the Ministry of Healthcare of Russian Federation). Another common reason for such a stereotype is Russian patriotism and belief in Russian national exclusivity. At the same time, however, more than $85 \%$ of the surveyed respondents stated that the quality of medical services (rehabilitation, care, hospital infrastructure) in Thailand is many times superior to the same services in Russia (Awadzi \& Panda, 2007; Heung et al., 2010).

The majority of Russians coming to Thailand for treatment specifically are interested in:

- regular health check (34\%), which in Thailand can be completed in one day visiting more than 5 doctors and passing all necessary tests;

-services of manual therapists, including specialists in ayurvedic massage and special massages for recovery after surgeries $(21 \%)$,

- cosmetic services (inoperable) (18\%),

- dental services (12\%),

- cosmetic services (operable) (9\%),

- body adjustment services (8\%).

From these results above it is rather obvious that the Russians perceive medical treatment in Thailand only as an additional service to accompany the standard leisure activities at the resorts. On the one hand, this opens up new opportunities for the tourist product oriented on Russian market modernization (for example, short-term programs for the whole family can be offered, such as a standard beach tour, but with the additional option to correct posture, cure platypodia, or normalize blood pressure, skin condition etc.) (Baimbetov et al., 2018; Tishchenko et al., 2018). On the other hand, this does not contribute to the development of high-tech medical tourism in Thailand, which would be always associated with the highest qualifications of specialists, modern equipment, specialized treatment (thus - with higher added value).

5. As the main problems faced by Russian tourists undergoing treatment in Thailand, they mention the following: the language barrier in the processing of documents' preparation (36\%), language barrier in direct communication (21\%), high cost of services (19\%), difficulty with making a choice (16\%), difficulty in further use of documents in Russia (15\%), high turnover of doctors in Thailand (9\%), narrow specialization of the local doctors (6\%).

These shortcomings of medical tourism in Thailand, contributed in the answers of Russian tourists, should be considered in more detail, considering the fact that they are 
becoming more and more known (via the Internet). Moreover, $36 \%$ of the interviewed by us had already heard before about the possible negative consequences of treatment in Thailand and the shortcomings of Thai medical product. Such quick spread of negative for reputation statement can significantly restrict the inbound medical tourism from Russia (Herrick, 2017). So, if the first problem - the language barrier - is a traditional problem for any hospital in any country, and it can be more or less easily solved by internal resources (for example, by introducing the positions of translators into Russian, outsourcing medical translations, by introducing a system for translating documentation into Russian), then the problems of the second level - complexity of choosing the right place for treatment and further use of Thai medical documents in Russia - are relatively newer problems, however, already having their negative impact on the attitude of tourists to treatment in the Kingdom (DeNavas-Walt et al., 2010).

Also, the Russians note that there is so much information available about the possibilities of treatment in Thailand, there is quite a variety of sources of its origin, thus, it is often difficult for them to decide on the place of receiving medical services. A tourist often makes a decision based on feedback and unreliable advertising information, and then later gets disappointed after the actual visit to a hospital or a clinic. The second problem is related to the inability to use documents obtained in a Thai clinic (hospital) later on in Russia. Russian doctors do not take into consideration the results of the tests conducted in Thailand, for several reasons. First of all, there are several discrepancies between the diagnostic standards in Thailand and Russia (for example, due to different systems of units and/or different methodologies), there is also a language issue since not many doctors back in Russia can read medical documentation in English. And finally, there is some sort of reluctance simply because doctors in Russia do not want to "lose money" which could have been earned if the diagnostics and/or part of treatment had been carried out in Russia but not in Thailand (UNWTO Tourism Highlights, 2016).

Also, the Russians overall speak negatively about the narrow specialization of Thai doctors, considering this approach as some sort of trick to make more money. Of course, such an attitude of patients and the fact that doctors in Thailand often combine several work places and thus have a very flexible work schedule also contribute to the negative attitude. On the one hand, this requires more flexibility from the clients (who must be ready to spend more time on the treatment and contact more than one doctor). On the other hand, turning the treatment process into a succession of easily replaceable doctors makes the client feeling he/she is not needed that much and is abandoned by a doctor. This, again, will not contribute to the positive image (Anand, 2009).

6. As a very positive can be considered the result of the last part in our survey concerning the prospects of Thailand as a place of treatment for Russian tourists. The majority of the respondents (71\%) expressed their readiness to be treated in Thailand in the future, or regularly undergo medical examinations and diagnostics in the Kingdom. However, it is worth highlighting some recommendations readily provided by Russian tourists, which can be regarded as recommendations for action. Thus, a significant share of our respondents recommended introducing business models of spa hotels in Thailand with the option of medical treatment being already included in the cost. For example, the cost of living in such hotels can include not only full board, but also some of the selected medical procedures (thermal baths, manual and physical therapy, aromatherapy, herbal therapy etc.). This kind of health services in Russia is widely spread from the middle of the twentieth century, which suggests the popularity of the identical accommodation facilities and tourist services at Russian-speaking markets (not only in Russia but almost in all other former Soviet republics) (Junevicius \& Albrektas, 2017; Anszperger, 2017). 


\section{CONCLUSIONS}

The sale of Thai tourist product on Russian market should be carried out more professionally and in a more specialized manner. Sale of health-improving tours to Thailand in the places of selling standard beach packages is proved to be absolutely inefficient, moreover, even damaging the sales to some extent, as it does not contribute to forming the needed serious attitude to health tourism in Thailand among Russian consumers. We find it logical to consider the option of opening the Internet offices for the sale of Thai health products in the framework of the national strategy for promoting the tourist potential of the Kingdom. Such Internet offices must be able to consult Russianspeaking consumers $24 / 7$ so that to recommend them to choose a place of treatment or rehabilitation in Thailand, as well as several options for acquiring tours (only through Russian affiliated travel agencies in order to follow the law of the Russian Federation).

Based on the advantages of Thai health product, highlighted by the Russians, we believe that in its promotion it is worth emphasizing on the excellent and high-tech service. Advertising should not show smiling nurses and chic wards in Thai hospitals, but concentrate more on the certificates, achievements, equipment etc.

Such facts are truly able to deliver the message that Thai medicine is quite advanced. For example, in the advertising messages, the texts such as "we conduct ten operations of coronary shunting every day", "equipment like ours can be found in ten only countries of the world" or "we have legal stem cells" should be more preferable than traditional "with love and care in single rooms with a park view".

To simplify the procedure of choosing the place for treatment and diagnosis, we consider it logical to propose a national system for assessing the achievements of hospitals and clinics in various areas of medicine, and to provide the hospital rankings based on the number of patients accepted and cured, patient reviews, compliance with international and national standards etc. The official rating can be determined every year or once in two years, and this rating must be freely available, so that any tourist in the world can look up in advance which hospitals in Bangkok perform the best operations on heart, which of them do best platics etc. A very important problem limiting the growth of Russian medical tourism in Thailand is the failure to accept Thai documents by Russian doctors. The reasons for this non-acceptance may be language, inconsistency of standards, unwillingness of Russian doctors to lose budgets for diagnostics. The first two problems from the above are easily solved through the introduction of a system for adapting Thai documents and diagnostic standards (this does not require significant expenditures, and each hospital can implement it independently after a series of consultations with Russian specialists, for example, during one conference). The third problem should be solved by Russian partners, actually. Options for its solution are seen only through the intensification of interstate cooperation in the field of medical care, development of partnership between Thai and Russian medical institutions. We can also recommend testing the economic and marketing effectiveness of a business model of a sanatorium in Thailand, that is, a modern accommodation facility that offers, in addition to traditional services, dietary and medical services (not medicamental, but for example, aromatherapy, homeopathy, physiotherapy, laser therapy, water, hydropathy, inhalation etc.).

This model will be somewhat more expensive than that of a traditional hotel, but unlike the hotel, it will have a set of strong competitive advantages in terms of Russian (and in the future, world) sales and will be able to actively earn additional services (diagnostics, treatment), use with the benefits of a medical facility in Thailand. This model, if successfully implemented, will open new prospects for the development of 
health tourism in Thailand, and maybe even form a whole brand new industry, directly connecting hospitality and medicine, and thus offering a new export tourist product with a potentially stronger demand from day one.

\section{REFERENCES}

Abaydeldinov, Y., \& Kala, N. (2016). International legal aspects of tourism activity: International treaties analysis. Journal of Advanced Research in Law and Economics, 7(4), 714-720.

Aimagambetov, E., Bugubaeva, R., Bespayeva, R., \& Tashbaev, N. (2017). Model of sustainable development of tourism industry in Kazakhstan (regional perspective). Public Policy and Administration, 16(2), 179-197.

Aizura, A. (2017). Where health and beauty meet: femininity and racialisation in Thai cosmetic surgery clinics. Asian Studies Review, 33(3), 303-317.

Anand, G. (2009). The henry ford of heart surgery. Available at http://online.wsj.com/article/SB12587589 2887958111.html. [Accessed 24 September 2019].

Anszperger, A. (2017). The role of public administration in tourism development in the case of the Torun county. Public Policy and Administration, 16(4), 553-566.

Awadzi, W., \& Panda D. (2007). Medical tourism: globalization and the marketing of medical services. The Consortium Journal, 75, 11.

Baimbetov A.K., Rzaev F.G., Nardaya Sh.G., Bizhanov K.A., Yergeshov K.A., \& Medeubekov U.Sh. (2018). New trends in interventional arrhythmology: the experience of two centers in the cryoablation of atrial fibrillation. Journal of Arrhythmology, 92, 5-10. DOI: 10.25760/VA-2018-92-5-10.

Balaban, V., \& Marano C. (2010). Medical tourism research: A systematic review. International Journal of Infectious Diseases, 14(1), 135. DOI: 10.1016/j.ijid.2010.02.1784.

Buathong, K., \& Lai, P.-C. (2019). Event sustainable development in Thailand: A qualitative investigation. Journal of Hospitality, Leisure, Sport and Tourism Education, 24, 110-119.

Burkett, L. (2007). Medical tourism. Journal of Legal Medicine, 28(2), 223-245.

Chistobaev, A.I., \& Semenova, Z.A. (2018). Spatio-temporal dynamics of the global medical tourism. Journal of Environmental Management and Tourism, 9(2), 267-275.

Chkalova, O., Efremova, M., Lezhnin, V., Polukhina, A., \& Sheresheva, M. (2019). Innovative mechanism for local tourism system management: a case study. Entrepreneurship and Sustainability Issues, 6(4), 2052-2067. http://doi.org/10.9770/jesi.2019.6.4(35).

Connell, J. (2006). Medical tourism: Sea, sun, sand and surgery. Tourism Management, 27(6), 1093-1100.

De Arellano, A. (2007). Patients without borders: the emergence of medical tourism. International Journal of Health Services, 37(1), 193-198.

DeNavas-Walt, C., Proctor, B.D., \& Smith, J.C. (2010). Income, poverty, and health insurance coverage in the United States: 2009. Washington: U.S. Government Printing Office.

Ehrbeck, T., Guevara C., \& Mango P. (2008). Mapping the market for medical travel. Health Care, 2, 1-11.

Font, X., \& Lynes, J. (2018). Corporate social responsibility in tourism and hospitality. Journal of Sustainable Tourism, 26(7), 1027-1042.

Grasso, F. (2014). Local governance, resources and tourism promotion: the case of taormina. Journal of Economics \& Sociology, 7(3), 170-178.

Herrick, D. (2007). Medical tourism: Global competition in healthcare. Dalas: National Center for Policy Analysis.

Heung, V., Kucukusta D., \& Song H. (2010). A conceptual model of medical tourism: implications for future research. Journal of Travel \& Tourism Marketing, 27(3), 236-251.

Junevicius, A., \& Albrektas, E. (2017). Analysis of opportunities for tourism development policy in Lithuania. Public Policy and Administration, 16(3), 439-454.

Keckley, P.H. (2017). Deloitte center for health solutions. Medical Tourism. https://www.academia.edu/ 9144718/Medical_Tourism_Consumers_in_Search_of_Value_Produced_by_the_Deloitte_Center_for Health_Solutions.

Khan, H.R. (2017). Impacts of tourism activities on environment and sustainability of Pattaya beach in Thailand. Journal of Environmental Management and Tourism, 8(8), 1469-1473.

King, R., \& Lertnapakun, P. (2019). Ambiguous heritage and the place of tourism: Bangkok's Rattanakosin. International Journal of Heritage Studies, 25(3), 298-311. 
Lerdsuchatavanich, P., Pradatsundarasar, A.-O., Pattanakiat, S., \& Utarasakul, T. (2016). Ecotourism is a significant tool for sustainable tourist attraction: A case study of Khao Krajome, Ratchaburi province, Thailand. Journal of Environmental Management and Tourism, 7(3), 481-492.

Momeni, K., Janati, A., Imani, A., \& Khodayari-Zarnaq, R. (2018). Barriers to the development of medical tourism in East Azerbaijan province, Iran: A qualitative study. Tourism Management, 69, 307-316.

Nonthapot, S., \& Srichaiyo, P. (2017). The relationships between financial policy, fiscal policy, visitor exports and the tourism economy of Thailand. Journal of Environmental Management and Tourism, 8(6), 1222-1231.

Nonthapot, S., Wattanakul, T., \& Wangkeeree, K. (2018). Spending behavior of Thai tourists in Dan Sai District, Loei province, Thailand: Seemingly unrelated regression estimation analysis. Journal of Environmental Management and Tourism, 9(5), 1062-1070.

Saraithong, W., \& Chancharoenchai, K. (2017). Investigating the reason why tourists revisit Thailand. Journal of Environmental Management and Tourism, 8(6), 1238-1249.

Smith, M., \& Puczko L. (2013). Health, Tourism and Hospitality: Wellness, Spas and Medical Travel. London: Routledge.

Sukhova, M.G., Zhuravleva, O.V., Vinokurov, Y.I., Chernova, E.O., \& Kaizer, M.I. (2018). Recreation and bioclimatic specifics of landscapes of the Central and South-Eastern Altai. Periodico Tche Quimica, 15(1), 537-547.

Tishchenko, A.L., Gorskii, V.S., \& Sergeeva, N.S. (2018). Linear skin atrophy: Current information and modern approaches to the external therapy. Medical News of North Caucasus, 13(3), 566-571.

Verdugo-Perona, J.J., Solaz-Portolés, J.J., \& Sanjosé-López, V. (2016). Development and validation of the first version of a questionnaire for measuring pre-service primary teachers' science content knowledge. Periodico Tche Quimica, 13(26), 140-150.

Veretekhina, S.V., Medvedeva, A.V., Vinichenko, M.V., Karyagina, T.V., \& Makushkin, S.A. (2017). Current trends influencing the competitiveness of international tourism. Journal of Advanced Research in Law and Economics, 8(2), 658-669.

Vetitnev, A., \& Dzubina A. (2013). Spa-services and sanatorium-resort complexes of Russia. Tourism: An International Interdisciplinary Journal, 61(2), 187-200.

Zhuravleva, O.V., Sukhova, M.G., Karanin, A.V., \& Malkov, P.Yu. (2018). Relative sustainability of the Altai transborder ecosystems. Periodico Tche Quimica, 15(30), 660-669.

*** Department of Health Annual Report 2016-17. 2017. https://www.health.gov.au/resources/publications/ department-of-health-annual-report-2016-17.

*** UNWTO Tourism Highlights. 2016. World Tourism Organization (UNWTO). https://www.eunwto.org/doi/pdf/10.18111/9789284418145.

Submitted:

26.10.2019
Revised:

23.12.2019
Accepted and published online

24.12.2019 